DOE/EA-1159

FINAL

ENVIRONMENTAL ASSESSMENT

\title{
DECONTAMINATION AND DISASSEMBLY OF THE
}

\author{
BIOLOGICAL IRRADIATION FACILITY
}

AT ARGONNE NATIONAL LABORATORY - EAST

ARGONNE, ILLINOIS

August 1996

DISCLAIMER

This report was prepared as an account of work sponsored by an agency of the United States Government. Neither the United States Government nor any agency thereof, nor any of their employees, makes any warranty, express or implied, or assumes any legal liability or responsibility for the accuracy, completeness, or usefulness of any information, apparatus, product, or process disclosed, or represents that its use would not infringe privately owned rights. Reference herein to any specific commercial product, process, or service by trade name, trademark, manufacturer, or otherwise does not necessarily constitute or imply its endorsement, recommendation, or favoring by the United States Government or any agency thereof. The views and opinions of authors expressed herein do not necessarily state or reflect those of the United States Government or any agency thereof. 


\section{DISCLAIMER}

Portions of this document may be illegible in electronic image products. Images are produced from the best available original document. 


\section{TABLE OF CONTENTS}

Section

Page

ACRONYMS

v

1.0 BACKGROUND 1

1.1 Facility History $\quad$ - 1

1.2 Facility Description 1

1.3 Current Status 3

$\begin{array}{llr}2.0 & \text { PURPOSE AND NEED } & 9\end{array}$

3.0 DESCRIPTION OF PROPOSED ACTION AND NO ACTION $\begin{array}{ll}\text { ALTERNATTVE } & 10\end{array}$

3.1 The Proposed Action 10

3.2 The No Action Alternative and Impacts 13

4.0 THE AFFECTED ENVIRONMENT $\quad: \quad 15$

4.1 Site Description $\quad 15$

4.2 Air Quality 15

5.0 ENVIRONMENTAL CONSEQUENCES OF THE PROPOSED ACTION 17

5.1 Environmental Impacts of Decontamination and Disassembly 17

5.1.1 Sensitive Resources 17

5.1.2 Waste Disposal Capacity . 17

5.1.2.1 Sanitary and Laboratory Wastewater $\quad 17$

5.1.2.2 Conventional Wastes 17

5.1.2.3 Hazardous Wastes 18

5.1.2.4 Mixed Waste 18 
TABLE OF CONTENTS (Continued)

Section

5.1.2.5 Radioactive Waste 18

5.1.2.6 Asbestos 19

5.1.3 Air Quality Impacts $\quad \cdot \quad 19$

5.1.3.1 Hazardous Emissions 19

5.1.3.2 Radioactive Emissions 19

$\begin{array}{lll}\text { 5.1.4 Noise Impacts . } & 20\end{array}$

5.1.5 Socioeconomic Impacts/Environmental Justice 20

5.1.6 Radiological Impacts 20

5.2 Environmental Impacts Of Transportation 21

5.3 Natural Hazards and Accidents 22

5.3.1 Natural Hazards 22

5.3.2 Accident Analysis $\quad 22$

5.3.2.1 Nature of Accidents 22

5.4 Other Potential Direct, Indirect, Cumulative, or Long-Term Impacts 24

5.5 Compliance with Regulations 24

5.6 Pollution Prevention 25

6.0 RELATIONSHIP OF THE PROPOSED ACTION TO $26^{\circ}$ OTHER ACTIONS BEING CONSIDERED UNDER OTHER NEPA REVIEWS 
TABLE OF CONTENTS (Continued)

Section

Page

7.0 REFERENCES

27

\section{List of Tables}

3-1 Proposed Activities 11

5-1 Radiological Exposure to Workers 21

\section{List of Figures}

1-1 Location of the JANUS Facility on the ANL-E Site 4

1-2 Location of the JANUS Facility in Building 202

1-3 Elevation Cross Section of the JANUS Facility 6

1-4 JANUS Facility Main Floor with Room Numbers 7

1-5 JANUS Facility Service Floor with Room Numbers 8 
ACRONYMS

ALARA As Low As Reasonably Achievable

ANL-E Argonne National Laboratory - East

ASA Auditable Safety Analysis

AQCR Air Quality Control Region

CCE Contamination Control Envelope

CEDE Committed Effective Dose Equivalent

CFR Code of Federal Regulations

$\mathrm{Ci} \quad$ Curie

CODE Committed Organ Dose Equivalent

D\&D Decontamination \& Decommissioning

DOE U.S. Department of Energy

EA Environmental Assessment

EBWR Experimental Boiling Water Reactor

EENF Environmental Evaluation Notification Form

EMO Environmental Management Operations

EPA U.S. Environmental Protection Agency

EPCRA Emergency Planning and Community Right-to-Know Act

FFCA Federal Facilities Compliance Act

ft Feet

HEPA High Efficiency Particulate (filter)

HVAC Heating, Ventilation and Air Conditioning

IAC Illinois Administrative Code

IEPA Illinois Environmental Protection Agency

$\mathrm{kg} \quad$ kilograms

lbs pounds

NEPA National Environmental Policy Act

NESHAP National Emission Standard for Hazardous Air Pollutants

NPDES National Pollutant Discharge Elimination System

NRC Nuclear Regulatory Commission

mrem Millirem

MW Megawatt

PCB Polychlorinated Biphenyl 
ACRONYMS (continued)

RCRA Resource Conservation and Recovery Act

TCLP Toxicity Characteristics Leaching Procedure

TEDE Total Dose Equivalent

TRU Transuranic

WMO Waste Management Operations

yr Year 


\subsection{BACKGROUND}

\section{$1.1 \quad$ Facility History}

The Biological Irradiation Facility (JANUS) was used to produce short-lived isotopes, by neutron absorption, needed in the research program of the Division of Biology and Medicine.

The facility was in operation from August, 1961 to March, 1992, to test the effects of neutron exposure in animals. The reactor was defueled and the fuel shipped off-site in 1993. All liquid systems were drained. These operations were conducted as part of the routine operations of the facility. The reactor had also been defueled/refueled in 1983.

\section{$1.2 \quad$ Facility Description}

JANUS is located in Building 202 (Figure 1-2). JANUS was housed within a brick building with thick concrete walls. This building encompasses the entire facility, with the exception of the cooling unit and stack which are located outdoors. The wing that contains the JANUS facility is $48^{\prime}$ by $60^{\prime}$ and occupies two floors, the one housing the reactor being below ground.

JANUS is a highly enriched uranium, light water-moderated and cooled assembly. The core consisted of nineteen elements of fuel jacketed in aluminum, located within a 4-foot diameter aluminum tank. The tank around the core is in turn surrounded by a graphite region. (Figure 1-3, 14 and 1-5).

JANUS was specifically designed as a facility to perform irradiations necessary for the research program of the Division of Biology and Medicine. The two irradiation faces supplied neutrons of essentially the same energy spectrum but of widely different intensity. This difference allowed relatively short, acute exposures on the high-dose side and prolonged chronic exposures on the lowdose side.

There is a high-level and a low-level dose room. The neutron flux in the high-level dose room was intense enough to provide acute irradiations for the animals under study. The neutron levels in the low level dose room are thought to have caused some activation to the materials in them although the intensity was significantly lower. 


\section{High-Level Side}

Acute studies required the use of the high-level face, and most of these were carried out with the highest dose rates obtainable (100-150 rad/min) at full power. These experiments were set up with shutters in place while the reactor was on. The duration of exposures on the high-level side did not usually exceed an hour.

\section{Low-Level Side}

The low-level side was intended to be used for chronic exposures. Although this side was not ever used for experimentation, neutron activation is possible as dose rate measurements were recorded in the room during the early part of the reactor's life. Concrete filled shutters stopped the radiation from either the high-level or low-level dose rooms when necessary. A lead wall beyond the shutter area prevented gamma rays from reaching the radiation area.

Adjacent to each of the dose rooms is a preparation room where specimens were prepared and cared for. These rooms contained instrumentation to indicate total dosage and dose rates being received by the specimens. The shutters and converter plates were controlled from the preparation rooms.

The reactor was operated from the control room which is located on the ground floor of the building. Also on the ground floor is an area above the reactor in which maintenance and refueling procedures took place. Large plugs in the floor of the maintenance/refueling area allow for access to the reactor from above.

The equipment for both a primary and secondary circulation system and for a helium system was located in the equipment room situated between the preparation rooms. An air-cooled radiator to cool the secondary system water is outside the building.

A building ventilation system provided proper control of humidity, temperature, and ventilation in the irradiation cells and the control room. The filters and blowers in this system served to remove particulate matter from the building atmosphere. A 75 foot exhaust stack served to dilute and disperse the air that was vented. 


\subsection{Current Status}

JANUS is no longer in use but remains contaminated with low level radioactive material and contains activated components following many years of operation. The reactor room and high dose room are considered activated. The primary water system is considered contaminated. The facility is in safe storage with on-going surveillance and maintenance activities taking place. A radiological characterization (Ref. 21) of JANUS was conducted in February and March, 1996.

Key points of the characterization findings are as follows:

- Total isotopic inventory is estimated at less than 28 millicuries, resulting in a Facility Classification of "Other Industrial Facilities."

- Approximately $99 \%$ of the total activity is in the graphite around the reactor tank.

- Except for one small spot of fixed contamination on the floor in the low dose room, no fixed or removable contamination was found on any wall, ceiling, floor, light fixture, or ductwork in the facility.

- Predominant nuclides detected were $\mathrm{Co}^{60}, \mathrm{Eu}^{152}$ and $\mathrm{Eu}^{154}$.

- Low levels of alpha contamination were found in only three locations: the glovebox, the rabbit tube, and the small spot on the floor of the low dose room $\left(100 \mathrm{dpm} / 100 \mathrm{~cm}^{2}\right.$, fixed). 


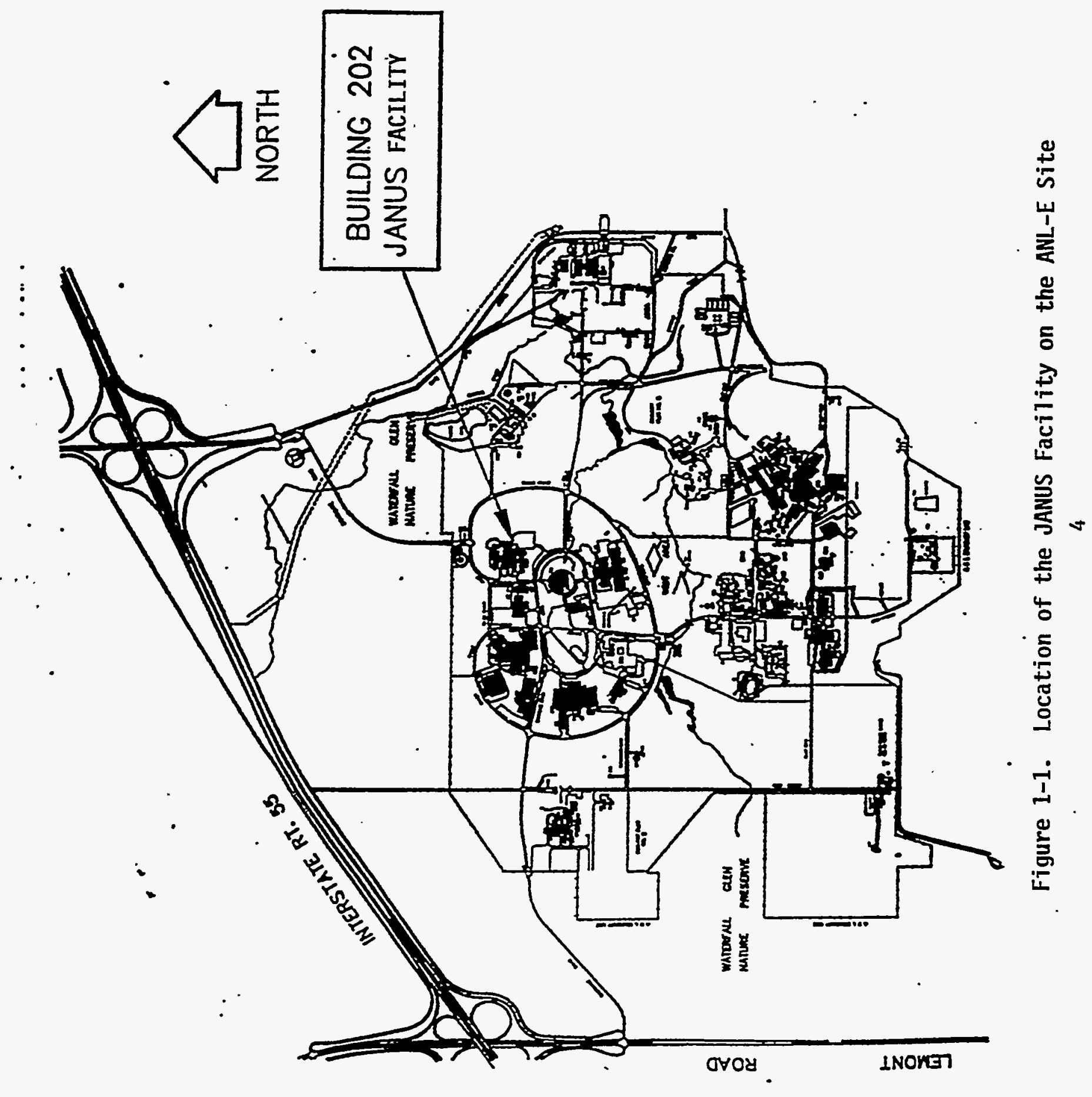




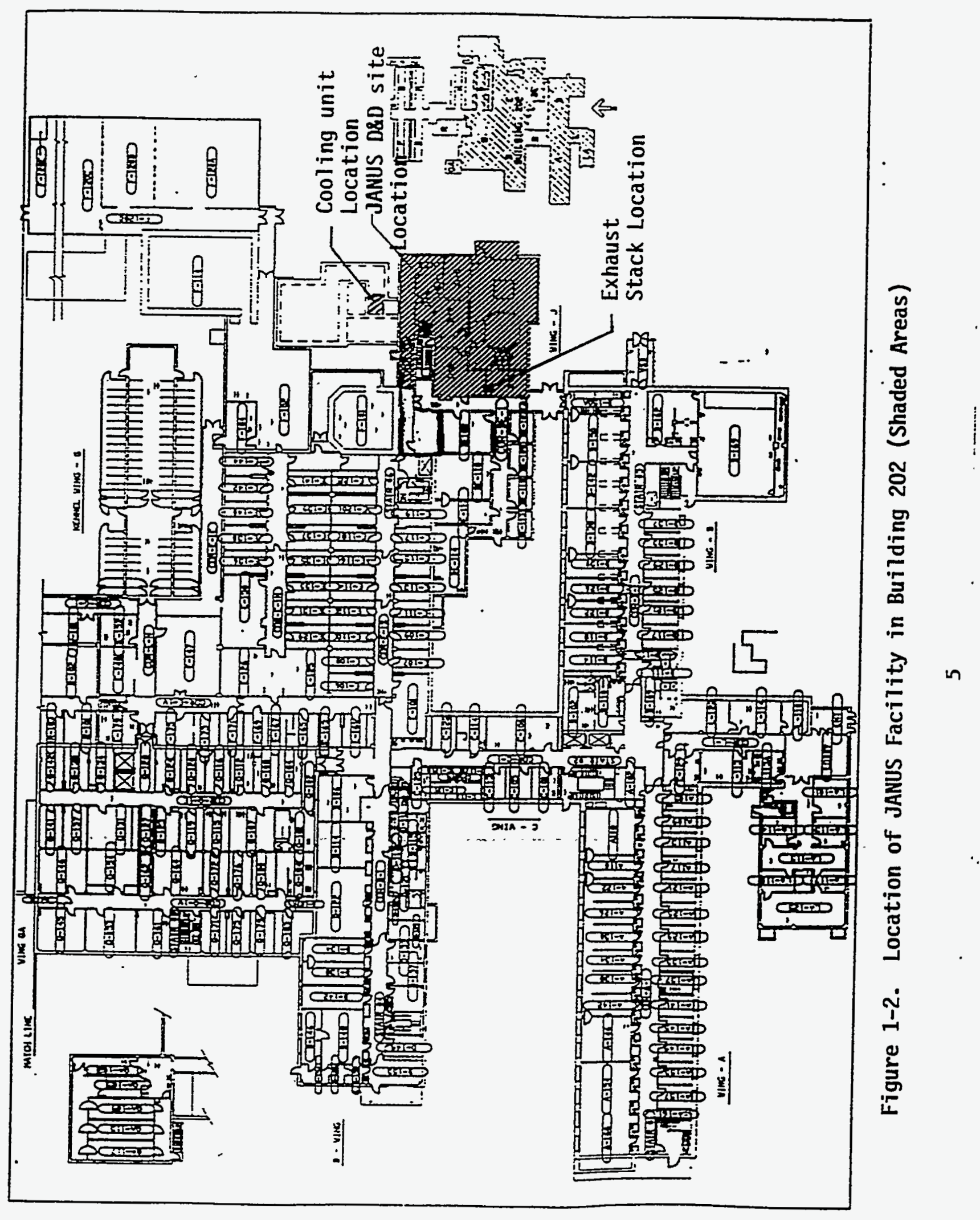




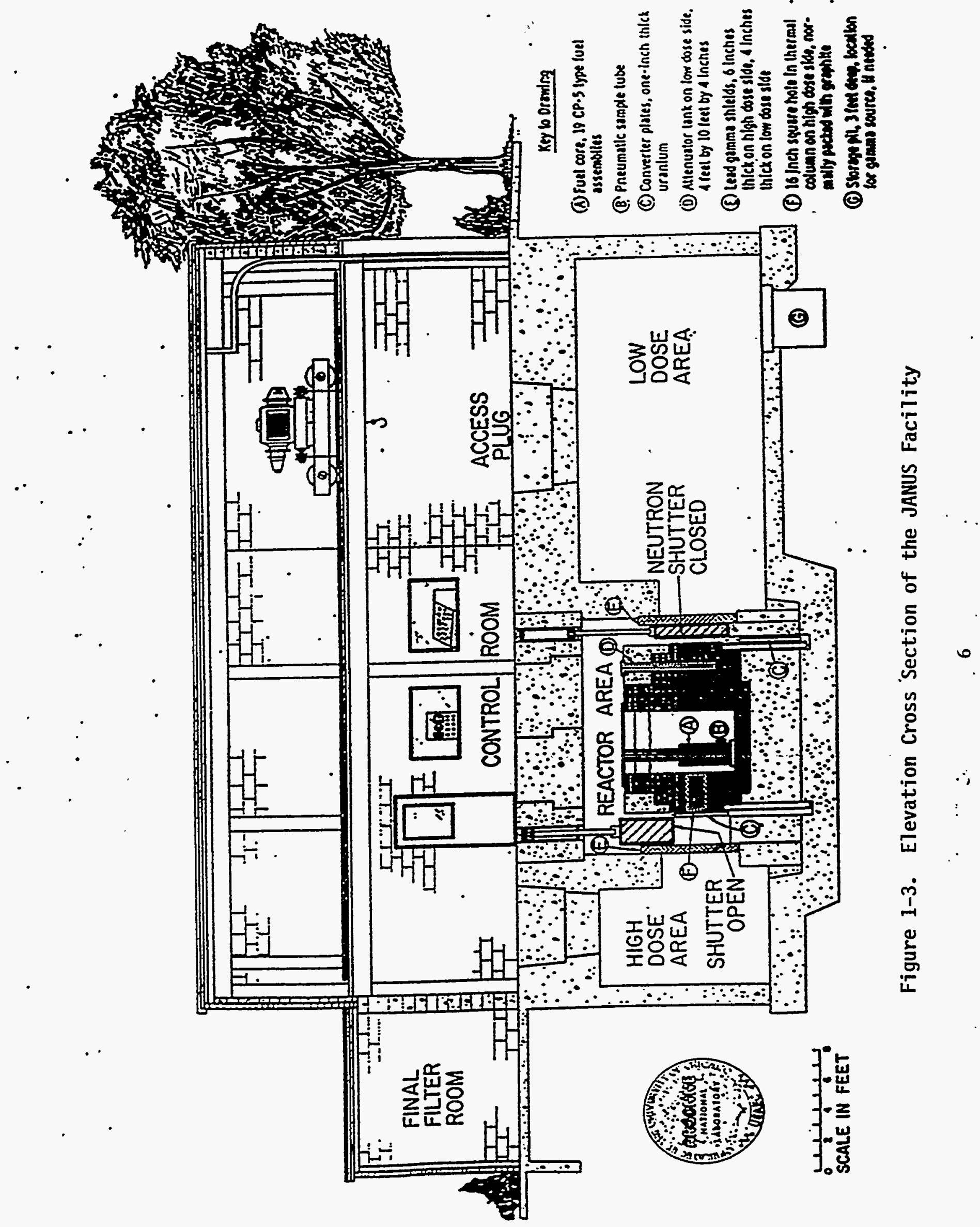



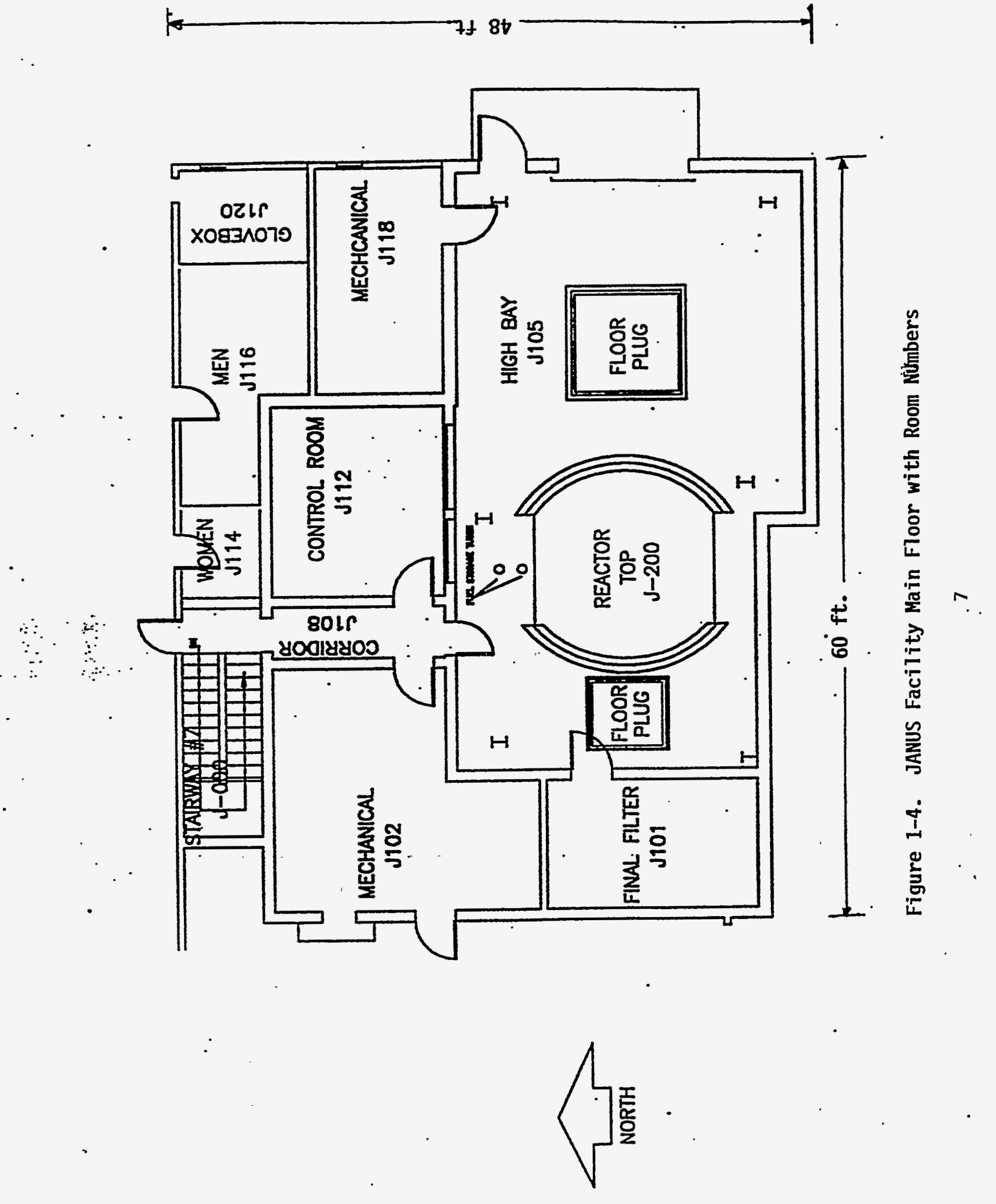


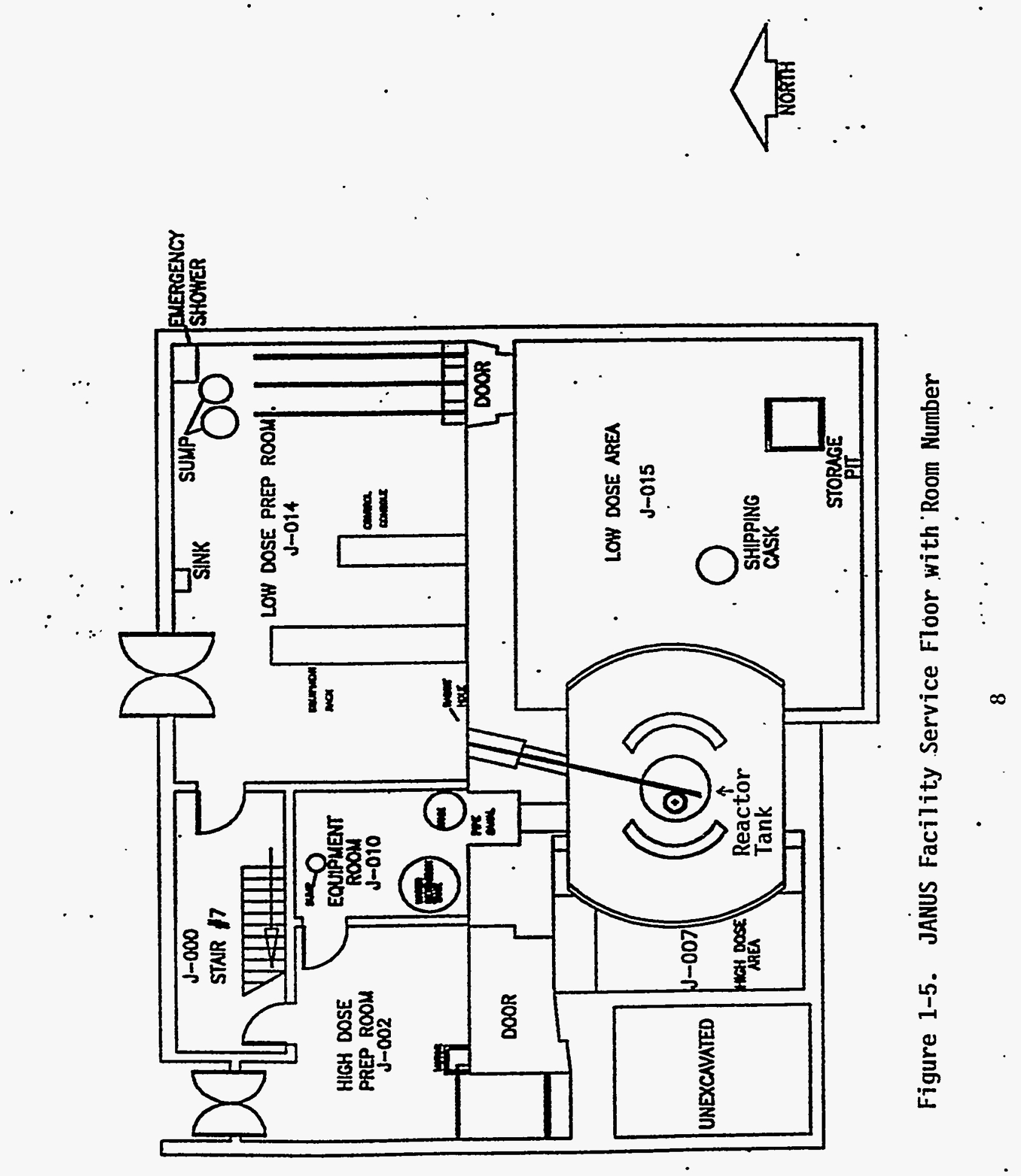




\subsection{PURPOSE \& NEED}

The purpose of this project is to accomplish, in part, the DOE/EM 40 program mission which is to protect human health and the environment from risks posed by inactive and surplus DOE facilities and contaminated areas, by remediating sites and facilities in the most cost efficient and responsible manner possible in order to provide for future beneficial use.

This project is needed to assure the protection of the health and safety of the public, DOE and contractor employees, and the environment, consistent with DOE Order 5820.2A, Radioactive Waste Management. Residual radioactivity from neutron activation is present in the reactor vessel, reactor structural components and shielding structures. Process systems and components that are contaminated would also be decontaminated and disassembled since these materials are in close proximity to nearby occupied areas. 


\subsection{DESCRIPTION OF PROPOSED ACTION \& NO ACTION ALTERNATIVE}

\subsection{The Proposed Action}

The proposed action is the decontamination and disassembly of JANUS, which includes activities such as disassembly, size reduction, packaging, and disposal. The majority of the work would be performed indoors of Building 202. The removal of the cooling unit and the exhaust stack are the only planned outdoor demolition work.

The proposed activities are broken down into phases of work, as listed in Table 3-1. These phases are organized around major components of the facility, and may be performed in a different order. For example, Phases VIII and IX may be performed after Phase I. Figures 1-4 and 1-5 denote the locations where the following activities would take place. 
TABLE 3-1 PROPOSED ACTIVITIES

\begin{tabular}{|c|c|}
\hline $\begin{array}{l}\text { PHASE OF } \\
\text { WORK }\end{array}$ & TYPES OF ACTIVITY DURING PHASE \\
\hline $\begin{array}{l}\text { I } \\
\text { Preparation of } \\
\text { Work Site }\end{array}$ & $\begin{array}{l}\text { Conduct radiological survey. Test for asbestos. Remove activated } \\
\text { racks for holding mouse cages. Disconnect electrical components. }\end{array}$ \\
\hline $\begin{array}{c}\text { II } \\
\text { Fuel Storage Tubes } \\
\text { (See Fig. 1-4) }\end{array}$ & $\begin{array}{l}\text { Decontaminate inner surfaces of fuel storage tubes and seal them for } \\
\text { disposal. }\end{array}$ \\
\hline $\begin{array}{c}\text { III } \\
\text { Low Dose Area } \\
\text { (See Fig. 1-5) }\end{array}$ & $\begin{array}{l}\text { Remove fuel transfer cask, miscellaneous equipment, and lead bricks } \\
\text { (from gamma shield and storage pits) to main floor. }\end{array}$ \\
\hline $\begin{array}{c}\text { IV } \\
\text { Low Dose Prep } \\
\text { Room (see Fig. 1-5) }\end{array}$ & $\begin{array}{l}\text { Decontaminate (if necessary) and remove sink, sump and drain } \\
\text { leading to the retention tank. Remove control console. }\end{array}$ \\
\hline $\begin{array}{c}\mathrm{V} \\
\text { High Dose Area } \\
\text { (see Fig. 1-5) }\end{array}$ & $\begin{array}{l}\text { Remove and dispose (as appropriate) of shutter drives and aluminum } \\
\text { mount of the high dose side. Remove contents of the high dose room } \\
\text { (e.g. steel I-beams, aluminum grating, an } 8 \text {-inch layer of borobauxite } \\
\text { concrete, } 4 \text { inches of lead, two air receiving tanks, three air cylinders, } \\
\text { converter and attenuator plate cables and pulleys) through the hatch } \\
\text { between the Main Floor and the High Dose Room. Remove } 56 \text { lead } \\
\text { sheets (approximately } 4 \text { feet high by } 8 \text { inches wide by } 1 \text { inch thick), } \\
\text { lead ceiling tiles, plugs and screws, and lead from walls and floor. } \\
\text { Remove the lead wall between the High Dose Room and Attenuator } \\
\text { Cavity and lead ledge from east side of room. Remove the borated } \\
\text { hard board behind the lead covering the walls and floor. }\end{array}$ \\
\hline $\begin{array}{l}\text { VI } \\
\text { Equipment Room } \\
\text { (See Fig. 1-4 and 1-5) }\end{array}$ & $\begin{array}{l}\text { Erect contamination controls (i.e., a catch containment beneath } \\
\text { primary components to capture any residual water within the piping) } \\
\text { prior to removal of the primary cooling water system. Remove the } \\
\text { remaining components of the secondary water system ( } 2 \text { pumps and } \\
\text { the two heat exchangers) as well as the remaining components of the } \\
\text { reactor helium system. Remove the cooling unit. Remove and } \\
\text { dispose of (as appropriate) the remaining components of the controls } \\
\text { for the skimmer and level control. Seal the pipe canal inside the room } \\
\text { before the contamination controls are removed. }\end{array}$ \\
\hline VII & move the shielding blocks from the Main Floor above the reactor. \\
\hline
\end{tabular}




\begin{tabular}{|c|l|}
\hline $\begin{array}{c}\text { PHASE OF } \\
\text { WORK }\end{array}$ & \multicolumn{1}{|c|}{ TYPES OF ACTIVITY DURING PHASE } \\
\hline $\begin{array}{c}\text { Biological } \\
\text { Irradiation Facility } \\
\text { (See Fig. 1-4) }\end{array}$ & $\begin{array}{l}\text { Install a Contamination Control Envelope (CCE), with proper HEPA } \\
\text { filtered ventilation, at the top of the reactor prior to removal of the } \\
\text { reactor components, shielding, and graphite. Remove the reactor tank } \\
\text { and other components with a crane. Survey the CCE interior surfaces } \\
\text { and decontaminate, if necessary, prior to dismantlement. }\end{array}$ \\
\hline $\begin{array}{c}\text { Main Floor } \\
\text { (See Fig. 1-4) }\end{array}$ & $\begin{array}{l}\text { Remove the glovebox in Room J-120, the HEPA filter unit in adjacent } \\
\text { room, and exhaust ductwork. }\end{array}$ \\
\hline $\begin{array}{c}\text { Control Room } \\
\text { (See Fig. 1-4) }\end{array}$ & $\begin{array}{l}\text { Remove the instrumentation within the control room on the main } \\
\text { floor. }\end{array}$ \\
\hline $\begin{array}{c}\text { X X } \\
\text { Exhaust System }\end{array}$ & $\begin{array}{l}\text { Remove and dispose of (as appropriate) contaminated ventilation } \\
\text { ductwork, filters, fan, and 75 foot tall exhaust stack located on the } \\
\text { roof of Building 202. }\end{array}$ \\
\hline $\begin{array}{c}\text { XI } \\
\text { Miscellaneous } \\
\text { Removal }\end{array}$ & $\begin{array}{l}\text { Remove the sanitary tank from hallway, the 75 kVA transformer } \\
\text { located beneath the stairs, and approximately 60 borax-filled, ten foot } \\
\text { long downspouts from the exhaust pit area. }\end{array}$ \\
\hline $\begin{array}{c}\text { XII } \\
\text { Final Survey }\end{array}$ & $\begin{array}{l}\text { Perform a final radiological survey to confirm the remaining structure } \\
\text { does not exceed the unrestricted release criteria. }\end{array}$ \\
\hline $\begin{array}{c}\text { XIII } \\
\text { Post Final Survey } \\
\text { Activities }\end{array}$ & $\begin{array}{l}\text { Fill the Main Floor fuel storage tubes and Low Dose Room storage pit } \\
\text { with concrete. Patch all openings resulting from removal of ductwork } \\
\text { and piping. }\end{array}$ \\
\hline $\begin{array}{c}\text { XIV } \\
\text { Site Closeout }\end{array}$ & $\begin{array}{l}\text { Demobilize site, and prepare the radiological survey report and } \\
\text { Project Closeout Data Package. }\end{array}$ \\
\hline
\end{tabular}

No hazardous materials would be introduced into the project area. Cleaning supplies, paint and decontamination solutions and other non-hazardous materials would be stored in cabinets designed for that purpose at the work site. Inventories would be kept to the minimum amount expected to be used and would be inventoried periodically.

A characterization of JANUS (Ref. 21) was completed in March, 1996. Based on sample analysis the following waste volume estimates are provided. 
Approximately 8.5 cubic meters ( 300 cubic feet) of asbestos insulation would be removed from piping and ventilation ductwork. Testing for asbestos would be performed before beginning decommissioning procedures. Asbestos found would be labeled and removed prior to starting any decommissioning work in those areas. Asbestos abatement would be conducted in accordance with the ES\&H Manual (Ref. 10), Chapter 4-4.

Hazardous waste in the form of lead paint dust would be accumulated during this project. Approximately 0.3 cubic meters ( 10 cubic feet) is expected to require packaging and shipment to a permitted RCRA storage facility in accordance with applicable regulations and DOE policies and procedures.

Approximately 45.3 cubic meters (1600 cubic feet) of contact handled low level waste would be generated, packaged and shipped to a DOE low level radioactive waste disposal site in accordance with $\mathrm{DOE}$ policies and procedures.

Approximately 0.4 cubic meters (15 cubic feet) of mixed waste (predominately activated lead) would be generated during this project. This material would be treated and/or disposed of in accordance with the proposed Federal Facilities Compliance Act Site Treatment Plan for Argonne-East. Current plans are to have ANL Waste Management Operations treat the lead by macro-encapsulation on-site. Permits are currently being revised to include this process. The remaining non-activated lead shielding (approximately 7.9 cubic meters, 280 cubic feet) would be reused at ANL-E (See Section 5.6).

\subsection{No Action Alternative And Impacts}

Under the no action alternative the Biological Irradiation Facility would not be decontaminated and the existing equipment would not be removed. The facility would be maintained as at present in a safe lay up condition. Surveillance and monitoring activities would continue to ensure adequate containment of radioactive contamination, provide physical safety and security controls and to preserve the facility to allow for personnel access. 
This alternative would preclude the use of this space for other activities and continue the Department's liability for the facility and would not allow the Laboratory to accomplish the EM 40 program mission. The reuse of lead shielding would also be precluded. This alternative would result in the continued radiation exposure to surveillance and maintenance personnel and the continued risk of release of material due to accidents or natural hazards. 


\subsection{THE AFFECTED ENVIRONMENT}

\subsection{Site Description}

ANL-E occupies 1,700 acres in southern DuPage County, Illinois and is shown on Figure 1-1 (Ref. 4). ANL-E is completely surrounded by the 2,040 acre Waterfall Glen Forest Preserve, which is used as a public recreational area, nature preserve, and demonstration forest. The ANL-E site is approximately 27 miles southwest of downtown Chicago and 24 miles west of Lake Michigan. The JANUS facility is located in a wing of Building 202 (Fig. 1-2).

The surrounding area is varied in land use and includes residential, commercial and industrial properties (Refs. 1,2). No resident population live within 1 mile of the center of the project site. Approximately 6,200 ANL-E, DOE and contractor employees, and no-pay appointees work at ANL-E (Ref. 4).

ANL-E is a region subject to tornadoes. Tornadoes have been observed in the area almost every month of the year, but are more active during April to June, and between 3:00 P.M. and 7:00 P.M. (Ref. 13). For the 30 year period 1954-1983, 89 tornadoes were recorded in the $1^{0}$ square $(9,275$ $\mathrm{km}^{2}$ ) of latitude and longitude containing ANL-E, an average of approximately 3 per year. The expected frequency of a tornado striking any given location ("point strike") in Illinois is $1.57 \mathrm{x}$ $10^{3}$ which is equivalent to return period of once every 637 years. Expected dimensions of this tornado would be $19.26 \times 0.17 \mathrm{~km}$, with an area of $7.56 \mathrm{~km}^{3}$ (Ref. 14).

No state listed threatened or endangered species are known to reside at the JANUS facility site. Also there are no cultural resource sites within the proposed project area.

\subsection{Air Quality}

Routine continuous monitoring of the permitted emission sources at ANL-E has indicated that the amount of radioactive material released to the atmosphere from these sources is extremely small, resulting in a very small incremental radiation dosage to the neighboring population. The calculated potential maximum individual off-site dose to a member of the general public for 1994 
was 0.015 mrem which, excluding radon -220 , is $0.15 \%$ of the 10 mrem per year EPA standard (Ref. 4).

Air monitoring was also conducted at ANL-E perimeter and off-site sampling stations for total alpha activity, total beta activity, strontium-90, isotopic thorium, isotopic uranium, and plutonium-239 (Ref. 4). No statistically significant difference was identified between samples collected at the ANL-E perimeter and samples collected off-site. 


\subsection{ENVIRONMENT AL CONSEQUENCES OF THE PROPOSED ACTION}

\subsection{Environmental Impacts Of Decontamination And Disassembly}

\subsubsection{Sensitive Resources}

Since the proposed activity would be conducted predominately indoors, there would be no environmental impact on the sensitive resources such as wetlands, floodplains, endangered species and cultural resources.

\subsubsection{Waste Disposal Capacity}

\subsubsection{Sanitary and Laboratory Wastewater}

The proposed action would involve less than twenty outside contractor personnel for about 5 months. They would represent a $0.13 \%$ increase in waste water handling requirements, well within the excess handling capacity of the laboratory system.

Small amounts of laboratory wastewater used during the project will be collected and sampled to determine if it meets laboratory wastewater discharge requirements or if it must be sent to Waste Management Operations (WMO) in Building 306 for processing. In either case, ANL-E has adequate waste handling capacity to manage the wastewater.

\subsubsection{Conventional Wastes}

The proposed action would generate approximately 59.4 cubic meters (2100 cubic feet) of noncontaminated waste materials such as concrete, metals and glass from structures and equipment. These materials would be disposed of by the contractor by offering certain materials to the scrap market for recycling, with the remaining conventional wastes to be disposed of at a municipal or commercial landfill which would have adequate capacity to accept the waste. Therefore, no disposal impact for this waste would be anticipated. 


\subsubsection{Hazardous Wastes}

The proposed action would generate approximately 0.3 cubic meters ( 10 cubic feet) of lead based paint removed from shield block surfaces. This hazardous waste would be disposed through a contract vendor in accordance with applicable ANL-E Waste Management Operations procedures and state RCRA requirements. A contract vendor that would have adequate capacity to dispose of this waste would be selected.

\subsubsection{Mixed Waste}

The proposed action would generate approximately 0.4 cubic meters ( 15 cubic feet) of mixed waste predominately in the form of activated lead. This material would be treated and disposed of in accordance with the Federal Facilities Compliance Act Site Treatment Plan for ANL-E. ANL Waste Management Operations would treat the lead by macro-encapsulation on-site and ship the treated lead to a commercial facility (i.e. Envirocare) for disposal. Permits are being revised to reflect this. After treatment and packaging the final disposal volume is estimated to be 3.4 cubic meters (20 cubic feet). This is well within the disposal capacity of the disposal site. Alternatively, the activated lead would be shipped to Envirocare where it would be treated and disposed.

\subsubsection{Radioactive Waste}

Approximately 45.3 cubic meters (1600 cubic feet) of low level radioactive waste would be generated by this project in the form of activated concrete and metal and contaminated paper, cloth and plastic. The major isotopes are $\mathrm{Co}^{60}, \mathrm{Eu}^{152}$ and $\mathrm{Eu}^{154}$. This material would be packaged and shipped to the DOE low level radioactive waste disposal site in Hanford, WA in accordance with Waste Management Operations procedures and DOE policies and procedures. This disposal site has adequate capacity to receive this waste. After packaging for shipment, this waste is estimated to require 65.1 cubic meters ( 2300 cubic feet) of disposal space. 


\subsubsection{Asbestos}

The proposed action would generate approximately 8.5 cubic meters ( 300 cubic feet) of asbestos waste. Testing for asbestos was completed during the characterization of the facility. The asbestos would be removed by an asbestos abatement contractor or WMO in accordance with applicable procedures for safe removal, handling, packaging, shipping, and final disposal. The disposal capacity for this waste would be adequate for either abatement contractor or WMO.

\subsubsection{Air Quality Impacts}

This project would not result in the release of any criteria pollutants.

\subsubsection{Hazardous Emissions}

Due to the small quantities of hazardous materials, the potential for hazardous emissions to the atmosphere is extremely small, and limited to minor and probably negligible amounts of dust containing lead or asbestos from materials described in Section 5.1.2.3 and 5.1.2.6.

\subsubsection{Radioactive Emissions}

The potential for radioactive emissions to the atmosphere is extremely small, and limited to minor and probably negligible amounts of dust containing radionuclides from materials described in Section 5.1.2.4 and 5.1.2.5.

These emissions would contain $\mathrm{Co}^{60}, \mathrm{Eu}^{152}$ and $\mathrm{Eu}^{154}$. Over $98 \%$ of all the radioactivity at the facility is in the graphite blocks around the reactor. These blocks would be removed by hand and placed in containers for disposal. Very little radioactive material is available to become airborne. 


\subsubsection{Noise Impacts}

Noise would be associated with the operation of machinery and equipment such as jack hammers, concrete saws and scrabblers, portable HEPA filters and fork lift trucks. Receptors of such noise would be limited to persons who work in or near Building 202. Noise impact to persons beyond the site and its buffer zone (Waterfall Glen Nature Preserve) would not be noticed because of the distances. The wearing of plug type personal protective equipment would be required for workers in areas posted as hearing protection required.

\subsubsection{Socioeconomic Impacts/Environmental Justice}

Total proposed action costs would be less than $\$ 5$ million. These expenditures would take place over two years and represents approximately $1 \%$ of ANL-E's annual operational expenditure. Thus the economic impact of the proposed action would be minor in the context of ANL-E and extremely small in the context of the regional economy. Temporary relocation of contractor personnel may be necessary for the duration of the project.

There would be no social impacts such as those related to relocation of residents or impacts on lifestyle and living conditions. The proposed action does not have a disproportionate effect on minority or low income populations and would in general have negligible effects on the surrounding community.

\subsubsection{Radiological Impacts}

The only radiological effect on non-project workers in building 202 or on the ANL-E site or members of the public would be from radiological emissions (section 5.1.3.2). Personnel exposures are expected to average 300 mrem per worker (Table5-1). Protective clothing, personnel monitoring devices and area radiation monitors with alarm capability would be used in conjunction with the project ALARA Program to keep personnel exposures reasonable.

Worker exposures to radiation under normal operations would be controlled under established procedures that require doses to be kept as low as reasonably achievable and that limit any individual's dose to less than $5 \mathrm{rem}$ per year. Based on an occupational risk factor of $4 \times 10^{-4}$ fatal 
cancers per person-rem, workers engaged in this proposed project would incur a $2.4 \times 10^{-3}$ risk of harmful health effects.

\section{TABLE 5-1 RADIOLOGICAL EXPOSURE TO WORKERS}

\begin{tabular}{|l|c|c|c|c|}
\hline $\begin{array}{l}\text { Activities Involving } \\
\text { Radiation Exposure }\end{array}$ & Number of Workers & Duration (Hours) & Area Dose Rate & $\begin{array}{l}\text { Total Exposure } \\
\text { (mrem) }\end{array}$ \\
\hline $\begin{array}{l}\text { High Dose Room } \\
\text { - Remove lead } \\
\text { ceiling }\end{array}$ & 2 & 34 & $3 \mu \mathrm{R} / \mathrm{hr}$ & 0.2 \\
\hline $\begin{array}{l}\text {-Remove Lead } \\
\text { Walls \& Floor }\end{array}$ & 2 & 66 & $3 \mu \mathrm{R} / \mathrm{hr}$ & 0.4 \\
\hline $\begin{array}{l}\text { Remove Reactor } \\
\text { Systems }\end{array}$ & 3 & 56 & $1 \mathrm{mR} / \mathrm{hr}$ & 168 \\
\hline $\begin{array}{l}\text { Remove Reactor } \\
\text { Tank }\end{array}$ & 3 & 22 & $3 \mathrm{mR} / \mathrm{hr}$ & 198 \\
\hline $\begin{array}{l}\text { Remove Graphite } \\
\text { Blocks }\end{array}$ & 3 & 83 & $10 \mathrm{mR} / \mathrm{hr}$ & 2490 \\
\hline
\end{tabular}

\subsection{Environmental Impacts Of Transportation}

Approximately 3 truckloads of clean waste, 4 truckloads of LLW and 1 truckload of mixed waste would leave the site for shipment of material to disposal sites throughout the five month duration of the project. This compares to the present off-site shipment of LLW of approximately 75 shipments per year.

The trucking firm used by ANL-E to transport LLW experienced an accident rate of 0.44 accidents per million miles in 1995. They experienced one fatality in the last three years. Average annual mileage is approximately 50 million miles, therefore the fatality rate would be 
0.006 fatalities per million miles. Additional waste shipments from the proposed action would result in an estimated 8,200 miles of transportation. This additional mileage would result in a 3.6 $\times 10^{-3}$ increased risk of accident and a $4.9 \times 10^{-5}$ increased risk of a fatality.

\subsection{Natural Hazards and Accidents}

An Auditable Safety Analysis (ASA) (Ref. 20) has been prepared for the proposed action. The major safety considerations are operational hazards, fire and natural phenomena hazards. The Biological Irradiation Facility is categorized as an "other industrial facility" in accordance with DOE STD 1027-92 (Ref. 22). The Hazard Analysis shows the potential for only localized consequences.

\subsubsection{Natural Hazards}

Risks associated with earthquake, lightning and floods are considered negligible (Ref. 20, Appendix I). All of the proposed disassembly work involving radioactive material would be done inside Building 202, a very substantial structure. The roll-up door to the main floor of the facility would not withstand the pressure differential of a tornado and would blow outward. However, the amount of loose hazardous and radioactive material in the area at any one time would be small and would consist only of materials discussed in 5.1.2. The possibility of a tornado is considered in the ASA (Ref. 20), and the impact of a tornado would be negligible.

\subsubsection{Accident Analysis}

\subsubsection{Nature of Accidents}

Accidents could occur in all proposed action operations including maintenance, on-site transportation, characterization, disassembly, packaging, transport for off-site disposal. These activities already have been conducted on-site. Accordingly, projections of expected future accidents can be based on past history.

Types of accidents which could occur include spills, fires, explosions, equipment failures, structural failures, and human error. 
The rate of deaths, injuries and health effects from the proposed action would be expected to be no greater than that experienced in operating ANL-E over the last ten years. In view of continued improvements in safety and health procedures, the expectation would be less than the period of record. Given the geographic locations and the nature of the proposed activities, the effects of accidents would likely be limited to the immediate work site and would not affect others at the ANL site or the general public. However, it is expected that the proposed action would improve existing safety conditions and reduce risks at this facility.

These factors indicate that accidental death, injury and loss associated with the proposed action are likely to range from minor to negligible.

The Auditable Safety Analysis (Ref. 20) for the proposed action addresses the accident analysis for each type of operation and prescribes the precautions to be taken to mitigate the hazards.

General requirements for minimizing the risk and consequences of accidents associated with activities such as proposed are contained in ANL-E procedures pursuant to requirements in federal and state regulations and DOE Orders which protect workers in hazardous environments as well as the public. These procedures, which are frequently updated, include measures for training, monitoring and oversight of activities with the potential for accidents (Refs. 10, 11, 12). These requirements include the preparation of Auditable Safety Analysis (ASA) for proposed new projects at radiological facilities.

Of particular relevance to the proposed action are Chapter 4 - Hazardous Materials and Chapter 5 - Radiological Control Manual of the Environmental, Safety and Health Manual (Ref. 10). In addition to required operating procedures and protective measures these chapters specify exposure limits and health maintenance measures. Other routine hazards associated with activities at ANL$\mathrm{E}$ are covered by other chapters. Also of particular relevance are required practices in the management of hazardous and radiological waste (Refs. 10,11).

\subsection{Other Potential Direct, Indirect, Cumulative, Or Long-Term Impacts}

Cumulative impacts are defined as "the impact which results from the incremental impact of the action when added to other past, present and reasonably foreseeable future actions...": All of the 
foregoing impact analyses take into consideration on-going ANL-E actions (Ref. 15). The incremental impact of the proposed action would not be significant if added to all other past, present and reasonably foreseeable future actions. Future actions (Ref. 2) are not anticipated to be within the vicinity of Building 202 during the duration of the project activities. The principal cumulative effect at issue is that the proposed action would reduce the environment, health and safety impacts, consequently it will have a positive effect at the ANL-E site. The specific future use is not known. Additional NEPA review would be preformed for any proposed re-use.

\subsection{Compliance With Regulations}

The proposed actions would comply with applicable federal, state and local laws. The applicable environmental laws and regulations are summarized below.

- Operating air permits for Building 202 (Clean Air Act).

- Asbestos removal and disposal at Building 202 (Clean Air Act and State Asbestos Abatement Law).

- Modification to existing RCRA Part B permit application for additional hazardous and mixed waste storage and treatment capacities and for closure of certain hazardous and mixed waste storage areas (Resource Conservation and Recovery Act).

- DOE Orders governing radioactive waste storage and decontamination/decommissioning of certain structures.

- DOT regulations. 


\subsection{Pollution Prevention}

The proposed action would enhance ANL-E's waste minimization and pollution prevention practices. Efforts would be made during the disassembly process to recycle approximately 90,900 $\mathrm{kg}(200,000 \mathrm{lbs})$ of lead brick and lead ceiling tile to the ANL-E Lead Bank for future use on-site. Efforts would also be made to recycle steel building materials and metal equipment that is not activated or contaminated. 


\subsection{RELATIONSHIP OF THE PROPOSED ACTION TO OTHER ACTIONS AND ACTIONS BEING CONSIDERED UNDER OTHER NEPA REVIEWS}

The proposed action is related to the Proposed Upgrade of Waste Storage Facilities Project which includes the treatment of mixed wastes (DOE-EA 1073). 


\subsection{REFERENCES}

(1) Argonne National Laboratory - East (ANL-E), 1993. FY 94 Site Development Plan. Document No. JOSTD-106-A-G-T005.

(2) Argonne National Laboratory - East (ANL-E), 1993. FY 94 Laboratory Integrated Facilities Plan. Document No. JOSTD-106-G-T006.

(3) Argonne National Laboratory-East (ANL-E), Five Year Plan for Environmental Restoration and Waste Management Program.

(4) Golchert, N. W. And R. G. Kolzow, 1995. Argonne National Laboratory-East Site Environmental Report for Calendar Year 1994. Document No. ANL-95/8.

(5) Herkert, J. R. (Ed.), 1991. Endangered and Threatened Species of Illinois: Status and Distribution, Vol. 1 - Plants. Illinois Endangered Species Protection Board, Springfield, IL.

(6) Illinois Department of Conservation, 1981. Endangered and Threatened Vertebrate Animals and Vascular Plants of Illinois.

(7) Bird, M. C., 1993. April 8 Letter from Bird (Conservation Archaeologist, Midwest Archaeological Research Services, Inc., Harvard, IL) to J. F. Hoffecker (Argonne National Laboratory-East).

(8) Environmental Evaluation Notification Form, Decontamination and Disassembly of the Biological Irradiation Facility, submitted to DOE on March 12, 1996.

(9) Environmental Assessment for the Proposed Remediation of 317/318/319/320/ENE Areas. Currently under preparation by Argonne National Laboratory-East.

(10) Argonne National Laboratory-East (ANL-E), 1994. Environmental, Safety and Health Manual. 
(11) Argonne National Laboratory-East (ANL-E), 1994. Waste Management Procedures Manual. JOSTD-102-G-T102.

(12) Argonne National Laboratory-East (ANL-E), 1994. Waste Handling Procedures Manual.

(13) McDonald, J. R., Assessment of Tornado and Straight Wind Risks at the Argonne National Laboratory (revision of 1979 document) prepared for the University of California, Lawrence Livermore National Laboratory, May 1983.

(14) Ramsdell, J. V. And G. L. Andrews, Tomado Climatology of the Contiguous United States, NUREG/CR-4461, prepared for U.S. Nuclear Regulatory Commission, 1986.

(15) Argonne National Laboratory - East (ANL-E), Site Environmental Reports for Calendar Years 1984-1993.

(16) Argonne National Laboratory-East (ANL-E), 1994. Pollution Prevention/Waste Minimization Program Plan.

(17) U.S. Department of Energy (DOE), 1994. Waste Minimization/Pollution Prevention Crosscut Plan.

(18) Argonne National Laboratory-East (ANL-E), 1994. Pollution Prevention/Waste Minimization Awareness Plan.

(19) Executive Order 12898 of February 11, 1994: Federal Actions to Address Environmental Justice in Minority Populations and Low-Income Populations.

(20) JANUS D\&D Auditable Safety Analysis, March, 1996.

(21) JANUS Characterization Report, March, 1996. 
(22) DOE STD 1027-92, Hazard Categorization and Accident Analysis Techniques for Compliance with DOE Order 5480.23, December, 1992. 


\title{
U. S. Department of Energy
}

\section{Finding of No Significant Impact}

\author{
Proposed Decontamination and Disassembly \\ of the Biological Irradiation Facility \\ at Argonne National Laboratory \\ Argonne, Illinois
}

AGENCY: $\quad$ U. S. Department of Energy (DOE)

ACTION: Finding of No Significant Impact (FONSI)

SUMARY: DOE has prepared an Environmental Assessment (EA) DOE/EA-1159, evaluating the decontamination and disassembly of the Biological Irradiation Facility (JANUS) at Argonne National Laboratory-East, Argonne, Illinois. The decontamination and disassembly work would assure the protection of the health and safety of the public, DOE and contractor employees, and the environment.

Based on the analysis in the EA, DOE has determined that the proposed action does not constitute a major federal action significantly affecting the quality of the human environment within the meaning of the National Environmental Policy Act of 1969 (NEPA). Therefore, the preparation of an Environmental Impact Statement is not required.

DESCRIPTION OF THE PROPOSED ACTION: DOE is proposing to decontaminate and disassemble the Biological Irradiation Facility. JANUS was used to produce short-lived isotopes, by neytron absorption. The facility was in operation from August 1961 to March 1992 to test the effects of neutron exposure in animals. As part of the routine operations of the Eacility, fuel was removed from the reactor ard shizped off-site in 1993. All liquid systems were drained at that time. Fi.e work currently proposed includes size reduction of reactor components and packaging and disposal of any waste. The majority of the work would be perforned inside the Biological Radiation Facility. The removal of a cooling uni= and the exhaust stack are the only planned outdoor demolition work.

ALTERNATIVES: Under the no action alternative the Biological Irradiation Facility would not be decontaminated or disassembled and existing equipment would not be removed. The facility would be maintained as at present in a safe lay-up condition and the building would not be available for reuse. The no action alternative would result in the continued minor radiation exposure to surveillance and maintenance personnel and the risk of release of radioactive material due to accidents or natural hazards.

ENVIRONKENTAI IMPACTS: Impacts of activities associated with the decontamination and disassembly of the Biological Irradiation Facility at Argonne National Laboratory-East were analyzed in the EA.

The FONSI for the proposed action is based on the following factors which are. supported by information and analysis in the EA.

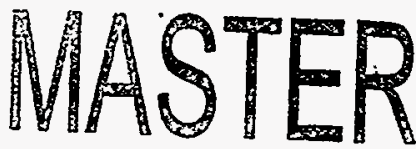


Sensitive Resources Impacts: None of the sensitive resources (e.g., wetlands, floodplain, endangered species, and cultural resources) would be affected by the project because the proposed action would be conducted indoors.

Waste Disposal Capacity Impacts: The disposal capacity of sanitary and laboratory wastewater on site would not be impacted because the proposed action would cause only a 0.138 increase in waste water handling requirement, well within the excess handling capacity of the laboratory. Conventional wastes would be recycled, if possible, municipal or commercial landfill contractors would have adequate capacity of accept the remaining waste. A contract vendor would have adequate capacity to accept the hazardous waste (lead based paint). Envirocare can easily accept the volume of mixed waste (predominately activated lead) generated. The Hanford, Washington, radioactive waste disposal site has adequate capacity to accept all low level radioactive waste (concrete, metal, and contaminated paper, cloth and plastic) generated by the project.

Air Quality Impacts: Due to the operation of the existing High Efficiency Particulate filters at the facility during the decontamination and disassembly, the proposed action would increase the radioactive emissions from ANL facilities by less than $1.4 \mathrm{millicurie}$ over the period of the work (approximately 5 months). This is a conservative estimate, and compares to a AivL-wide emission of approximately 370 curies. The maximally exposed member of the general public would experience an increase of 0.002 millirem to a total from all lab emissions of 0.014 millirem.

The allowable exposure (per $40 \mathrm{CFR}$ 61) is 10 millirem and a typical individual's exposure from all normal radiation sources (cosmic rays, household, and workplace) is approximately 360 millirems. Potential releases of hazardous compounds would be small and have no adverse effects.

Noise Impacts: Noise impacts would be limited to specific operations in Building 202. Personnel would be required to wear protective equipment in areas where noise would be a health hazard.

Socioeconomic Impacts/Environmental Justice: The total cost of the proposed action, over two years, would be less than 18 of the ANL-E annual operational expenditure. The economic impact of the proposed action would be minor in the context of ANL-E and extremely small in the context of the regional economy.

The proposed action does not have a disproportionate effect on minority or low income populations and would in general have negligible effects on the surrounding community.

Radiological Impacts: Radiation exposure to personnel doing the decontamination and disassembly work would be monitored closely. The exposures are expected to be no greater than 300 mrem. Any worker exposures would be carefully controlled under procedures followed in the As Low As 
Reasonably Achievable program. The proposed action would contribute a negligible and probably undetectable increment to existing levels of direct public exposure as monitored by ANL-E.

Transportation Impacts: Transportation impacts would be limited to about eight truck trips to ship waste from the site. This compares to the present off-site shipment of low level waste of approximately 75 shipments per year. The increase in risk of accidents would be 0.006 fatalities per million miles, which is extremely low.

Natural Hazards and Accidents Impacts: Risks associated with natural hazards are considered negligible. Accidents projected for the-proposed action are based on past history of similar activities that were conducted on site. Accidents associated with the proposed action are likely to range from minor to negligible.

Other Potential Direct, Indirect, Cumulative, or Long-Term Impacts: The incremental impact of the proposed action would not be significant if added to all other past, present and reasonably foreseeable future actions. The proposed action alternative would reduce the environment, health and safety impacts, consequently it will have a positive effect at the ANL-E site.

Compliance with Regulations: ANL-E has the ability to comply with all applicable Federal and IIlinois regulations.

Pollution Prevention: This action would allow the beneficial recycling of over $90,900 \mathrm{~kg}$ (200,000 pounds) of lead and the sale of some steel scrap and would enhance the AVL-E iaste minimization and pollution prevention program.

DETERMINATION: Based on the analysis in the EA, the DOE has determined that the proposed Decontamination and Disassembly of the Biological Irradiation Facility at Argonne National Laboratory-East does not constitute a major federal action significantly affecting the quality of the human environment within the meaning of the National Environmental Policy Act of 1969. The proposed action alternative would have the least environment, health and safety impact and is the most efficient and cost effective. Therefore, an Environmental Impact Statement on the Proposed Action is not required.

PUBLIC AVAILABILITY: Copies of the EA (DOE/EA-1159) are available from:

Timothy S. Crawford

Argonne Group Manager

9800 South Cass Avenue

Argonne, Illinois 60439

(630) 252-2436 
$-4-$

For further information regarding the DOE NEPA process contact:

Dr. W. S. White

NEPA Compliance Officer

Chicago Operations Office

9800 South Gas Avenue

Argonne, Illinois 60439

(630) 252-2101

Issued in Argonne, Illinois, this

$28^{\beta^{2}}$

Day of August

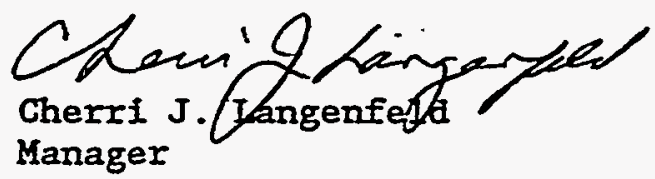



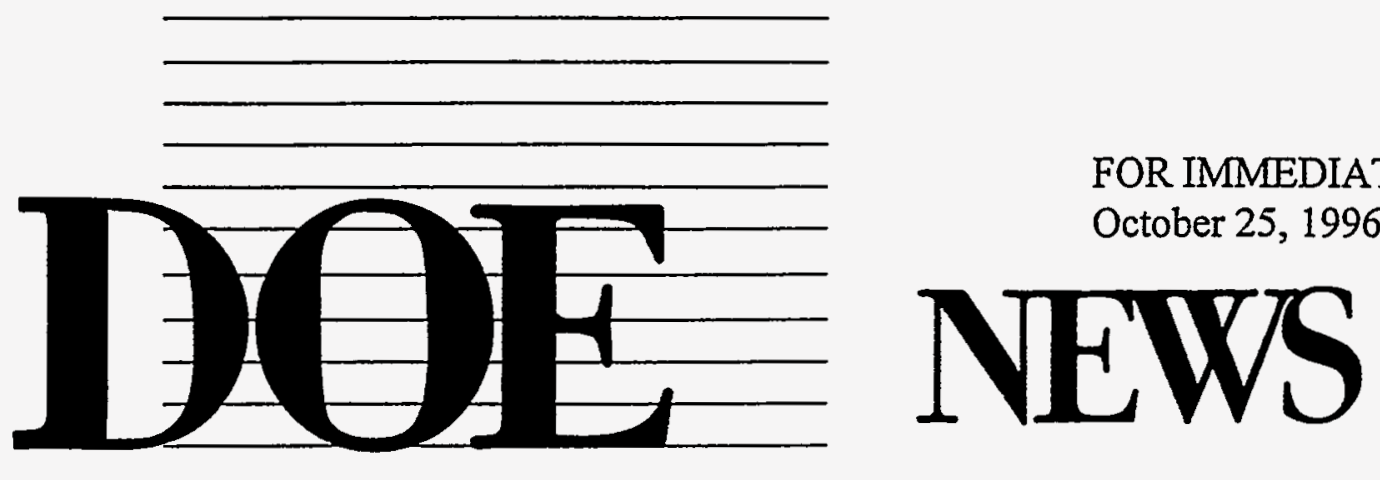

\section{U.S. DEPARTMENT OF ENERGY PROVIDES ENVIRONMENTAL DOCUMENTS ON DECONTAMINATION OF JANUS REACTOR}

Two environmental documents evaluating the proposed decontamination and disassembly of the JANUS Reactor at Argonne National Laboratory - East (ANL-E) are available for public review from the U.S. Department of Energy (DOE). This project is expected to cost approximately $\$ 4.1$ million, and is expected to start in January and be completed by September 1997.

The JANUS Reactor was used to produce short-lived isotopes needed in the research program of the Division of Biology and Medicine. The reactor was in operation from August 1961 to March 1992. The fuel was shipped off-site in 1993.

The Environmental Assessment (EA) and Finding of No Significant Impact (FONSI) documents assure that the decontamination and disassembly work will not have significant impact on the health and safety of the public, DOE employees and contractors or the environment.

The proposed project will include size reduction of reactor components and packaging and disposal of any waste. The majority of the work will be performed inside the Biological Radiation Facility. The removal of a cooling unit and the exhaust stack are the only planned outdoor demolition work.

-- more --

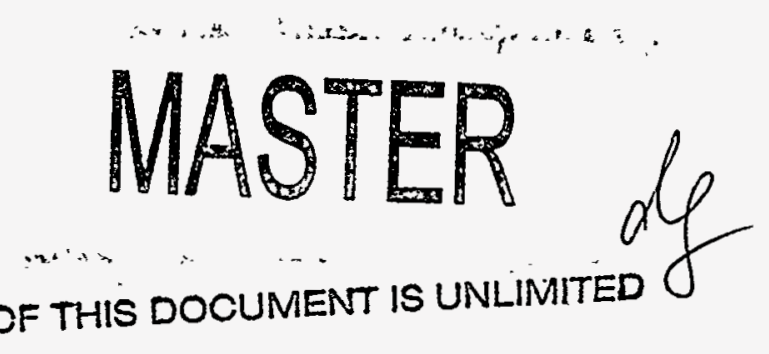

DISTRIBUTION OF THIS DOCUMENT IS UNLIMITED 
The Department's Environmental Assessment analyzes the environmental impacts that might occur as a result of these actions. The EA analyzed impacts in these areas:

radiological, socioeconomic, air quality, pollution prevention, and natural hazards. The Finding of No Significant Impact determined that the proposed action does not constitute a major federal action significantly affecting the quality of the human environment within the meaning of the National Environmental Policy Act of 1969 (NEPA).

To allow interested citizens to review the EA and FONSI, DOE has placed copies of them in the Reference Room at the DOE Reading Room on the campus of the University of Illinois at Chicago, 801 S. Morgan Street, Chicago, Illinois; and at two area libraries: Lemont Public Library, 810 Porter Street, Lemont, Illinois; and Indian Prairie Public Library, 401 Plainfield Road, Darien, Illinois.

Copies of the EA and FONSI are available from:

Timothy Crawford, Manager

Argonne Group

U.S. Department of Energy

9800 S. Cass Avenue

Argonne, IL 60430

For further information on the NEPA process:

Dr. W.S. White

NEPA Compliance Officer

U.S. Department of Energy

9800 S. Cass Avenue

Argonne, IL 60439

Argonne National Laboratory is operated for DOE by the University of Chicago.

- DOE-

DOE News Media Contacts: Brian J. Quirke (630) 252-2423

Jessie L. Lane (630) 252-2420 